\title{
APPLICATION OF MATHLAB APPLICATIONS IN IMPROVING STUDENT COMPETENCE UMSU MATHEMATICS EDUCATION STUDY PROGRAM NUMERICAL METHOD COURSE 2019-2020 ACADEMIC YEAR
}

\author{
Indra Maryanti \\ Universitas Muhammadiyah Sumatera Utara \\ E-mail: indramaryanti@umsu.ac.id
}

\begin{abstract}
This study aims to describe the role of MATHLAB software in numerical method lectures, improve students' ability to solve numerical problems through learning assisted by MATHLAB software, improve students' abilities in formulating algorithms through learning assisted by MATHLAB software, improve students' abilities in programming through assisted learning MATLAB software; and describing student responses after numerical learning assisted by MATLAB software. This research is a quantitative research. To prove the hypothesis and answer the problems in this study, several statistical tests were carried out as follows:

1. Test the description of the data, namely: making a data frequency table, testing the average value, and standard deviation.

2. Prerequisite test, namely: normality test with Liliefors table and homogeneity test.

3. Hypothesis testing, namely: statistical tests to see how much improvement in student competence is using the MATLAB software application in the numerical method course. The tests used are regression and correlation tests to see the increase in student competence using the MATLAB software application.

The research method used is experimental. The population of this research is UMSU 7th semester students in the 2019/2020 academic year as many as 98 students.
\end{abstract}

Keywords: Numerical, MATLAB, Math

\section{INTRODUCTION}

The Indonesian National Curriculum Framework (KKNI) requires students to have additional skills in addition to knowledge in the chosen scientific field, for example, mastery of computer technology. To support the mastery of technology in mathematics, it is necessary to introduce and train several software related to mathematics and mathematics education, including geometric animation with CABRI software, data analysis using SPSS software, even simple software commonly used by students outside the mathematics education department. , for example excel, word, power point, macro flash and so on. This software can be used in calculus courses, basic mathematical concepts, matrix algebra and linear algebra, discrete mathematics, numerical methods, real analysis,

Numerical method is one of the subjects considered difficult by mathematics education students. These courses are used to be difficult to answer using analytical methods. Based on the results of pre-research in May 2013 on the subject of numerical methods. shows a lack of student interest in the subject and students are less active during class learning. In addition, based on observations that it is difficult to find teaching materials for numerical methods courses that are assisted by software in the mathematics education environment of the Muhammadiyah University of North Sumatra.

Numerical method discusses numerically from each problem presented. Unlike other sciences, for example, analysis and algebra can be solved by means of algorithms and analysis to determine the solution. The Numerical Method discusses material about how to find a solution or solution to a problem that cannot be solved by using a formula directly. In the Numerical method, the analysis of 
the formula used is not an obstacle but is more focused on how the algorithm thinks students use existing formulas to find solutions. Along with the development of computer science, one of the software that can be used to help with numerical problems is MATLAB software.

For example, usually in mathematics the question is given: determine the value of $\mathrm{x}$ for the function, although it looks difficult to solve, but the problem can still be found for the value of $x$ that satisfies the equation equal to zero $(\mathrm{f}(\mathrm{x})=0)$ analytically. In contrast to the following problem, determine the value of the function. Polynomial power problems will be difficult to solve analytically, therefore they need to be solved numerically.

$$
f(x)=2 x^{3}+x^{2}-5 x+8 f(x)=2,25 x^{7}+20 x^{6}-5,6 x^{5}+15 x^{3}-100 x-125
$$

The explanation of concepts in numerical methods assisted by MATLAB software will train students to sharpen the preparation of problem solving algorithms which are then translated into computer language and then the computer itself will carry out the calculation process if the instructions are clear. Students can determine how many loops or iterations they want. Because computers in numerical methods have a role to speed up calculations without making mistakes and trying various possibilities that occur due to parameter changes.

\section{LITERATURE REVIEW}

\subsection{Learning and Learning Outcomes}

Learning is the most important activity in the whole educational process. Gagne explained that learning is a complex process and learning outcomes are abilities caused by: (1) stimuli originating from the environment and (2) cognitive processes carried out by students. Once people have skills, knowledge, attitudes and values. Learning occurs when there are observable results.

Learning outcomes are related to students' abilities in understanding lecture material. According to Hamalik (2007: 31) suggests, "learning outcomes are patterns of actions, values, understandings, attitudes, appreciation, abilities and skills".

Mathematics learning outcomes are an illustration of the level of cognitive ability obtained in the form of knowledge and skills. In the form of knowledge, including facts, concepts, procedures and mathematical principles, it will be meaningful or meaningful for students if they are connected with facts that exist in students' daily lives.

Mathematics education students study numerical methods courses in the seventh semester. The material studied in the numerical methods course is non-linear equations, linear equations, interpolation, numerical integration, numerical derivation of functions, and numerical solution of differential equations.

\subsection{Numerical Method}

Numerical methods are the techniques used to formulate mathematical problems so that they can be solved. Calculations in numerical methods involve a large number of repeated calculation operations. Many mathematical problems cannot be solved analytically but can be solved using numerical methods.

Mathlab is a program that is used to analyze and calculate numerically using an advanced mathematical programming language. According to Sianifar (2013) states that mathlab can be used to solve mathematical problems and aids in the learning process. Some mathematical concepts that can be described using Mathlab include matrices, vectors, linear algebra, interpolation, integrals and ordinary differentials.

\section{IMPLEMENTATION METHOD}

The type of research used in this research is Classroom Action Research (CAR). CAR is action research conducted with the aim of improving the quality of classroom learning practices. This research was conducted in the Mathematics Education Study Program, Faculty of Teacher Training and Education, University of Muhammadiyah North Sumatra for the 2017/2018 academic year. The 


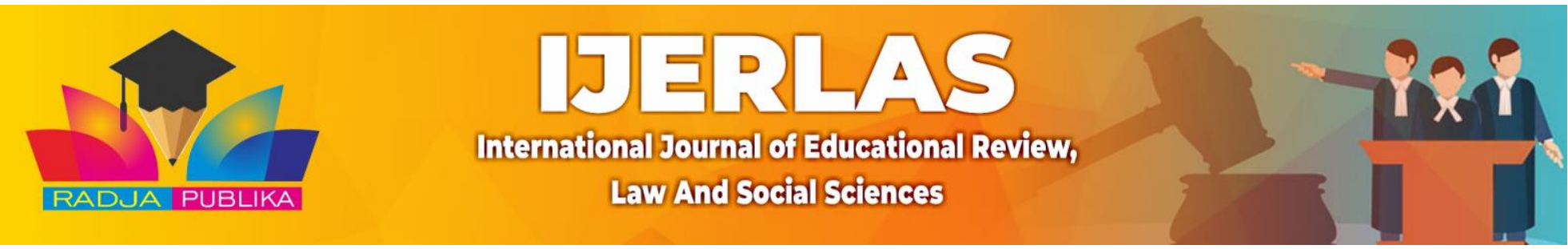

object of this research is 7C grade students in the Mathematics Education Study Program, Faculty of Teacher Training and Education, Muhammadiyah University of North Sumatra. The object of the research is the implementation of learning using mathlab simulation media as an effort to improve students' understanding of concepts.

\section{RESULTS AND DISCUSSION \\ 4.1 RESULTS}

\subsubsection{Research result}

This research was carried out in two cycles, each cycle consisting of 4 stages, namely the planning, implementation, observation, and reflection stages. The results of the study started from the pre-cycle then continued to cycle I and cycle II. Until it reaches the predetermined indicator. The results showed that by applying the simulation media using mathlab in learning can improve students' understanding. This can be seen from the results of observations of the implementation of learning, the results of the concept understanding test, the results of the student response questionnaires.

1. Analysis of the implementation of learning on the results of observation of learning activities in the first cycle the percentage of implementation of all indicators during the learning process was $71.43 \%$, in the second cycle it rose to $83.93 \%$. There are two observers in the study. The implementation of indicators in the observation of the implementation of activities can be seen in the following table:

Table 4.1 Results of Observation of Cycle I and Cycle II

\begin{tabular}{|c|l|c|c|}
\hline \multirow{2}{*}{ No. } & \multicolumn{1}{|c|}{ Indicator } & \multicolumn{2}{c|}{$\begin{array}{c}\text { Percentage } \\
\text { Achievement }\end{array}$} \\
\cline { 3 - 4 } & & Cycle I & Cycle II \\
\hline 1 & Delivering learning indicators and motivating students & $75.00 \%$ & $87.50 \%$ \\
\hline 2 & Explain in outline the material being studied & $75.00 \%$ & $87.50 \%$ \\
\hline 3 & Delivering how to use mathlab simulation media & $87.50 \%$ & $87.50 \%$ \\
\hline 4 & Distribute LKM and ask students to work on & $62.50 \%$ & $87.50 \%$ \\
\hline 5 & Lecturers observe and help students if they have difficulties & $62.50 \%$ & $75.00 \%$ \\
\hline 6 & Lecturer appoints students to present their work & $75.00 \%$ & $87.50 \%$ \\
\hline 7 & $\begin{array}{l}\text { Lecturers and students together conclude the material that has } \\
\text { been studied }\end{array}$ & $62.50 \%$ & $75.00 \%$ \\
\hline \multicolumn{2}{|c|}{ Average Percentage } & $71.43 \%$ & $83.93 \%$ \\
\hline
\end{tabular}

2. Comprehension Test Results

Cycle I and II test results are given to students after being treated and given at the end of the cycle. The following are the results of the first and second cycle tests.

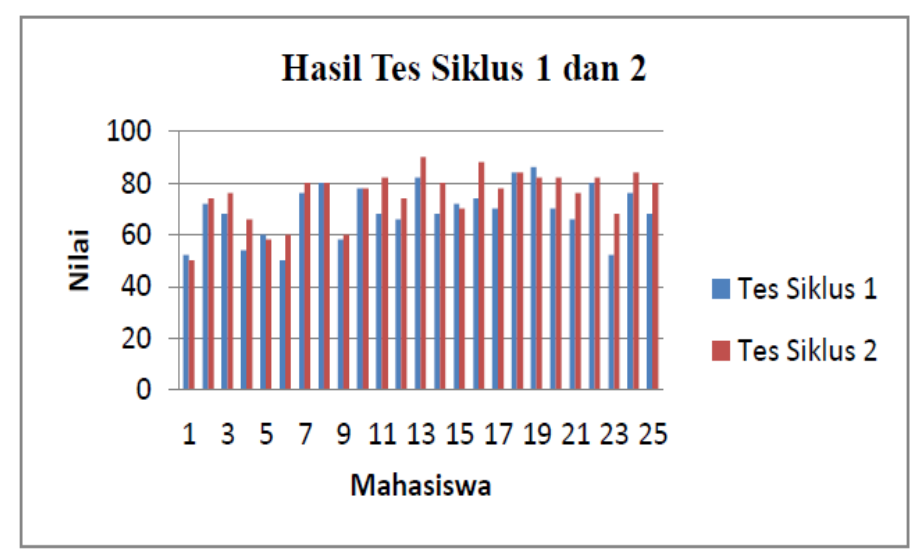

Figure 1 Graph of cycle 1 and 2. test scores 
From the test results, it was found that the average of the first cycle test was 69.20 and the second cycle test average was 75.28. There was an increase in the average value of the class from cycle I to cycle II.

3. Student Response Questionnaire

Student response questionnaires were given after students used mathlab simulation media in learning. From the student response questionnaire, data were obtained about student responses to learning. The results of the scores for each question item in the student response questionnaire are percentage and qualified to determine student responses. Based on the results of the response questionnaire, students gave a high response in learning by using mathlab simulation media. From the student response questionnaire, the percentage of student responses was $78.93 \%$. This shows that after learning to use mathlab simulation media, students' responses to learning are included in the "High" qualification.

\subsection{DISCUSSION}

The system of linear equations is one of the mathematical models and problems that are often encountered in various disciplines, including physics, biology, engineering, etc. The system of linear equations arises directly from the real problem, and is part of the process of solving other problems, for example solving a system of simultaneous non-linear equations. A system of linear equations is a system of equations consisting of a (finite) number of equations and a (finite) number of variables. Looking for a solution to a system of linear equations is to find the values of these variables, so that they fulfill all the systems of equations. There are two methods for finding solutions to systems of linear equations, namely:

1. Direct method, which consists of Gaussian elimination method, Gauss-Jordan elimination method, inverse matrix method and LU decomposition method.

2. Indirect method namely the iteration method, which consists of the Jacobi iteration method and the Gauss-Seidel iteration method, where in this iteration method an initial solution must be given (which is a guess).

\section{CONCLUSION}

Based on the results of the study, several conclusions were obtained

1. The use of MATHLAB software in learning the Numerical method of the subject of Simultaneous Linear Equation Systems will be very helpful for students, because students can easily perform iteration calculations using the algorithm created in MATHLAB. In addition, the use of MATLAB software can motivate students to take Numerical Method lectures.

2. The application of mathlab simulation media can improve students' understanding of concepts in the system of linear equations. This is indicated by an increase in the average percentage of students' understanding of concepts, namely in the first cycle of $69.20 \%$, increasing in the second cycle of $75.28 \%$.

\section{REFERENCES}

Arsyad, A. (2011). Media Pembelajaran Matematika. Jakarta: Raja Grafindo Persada. Depdiknas. 2003.Kurikulum 2004 Standar Kompetensi Mata pelajaran Matematika.Jakarta.

Depdiknas. 2003. Kurikulum Berbasis Kompetensi Mata Pelajaran Matematika. Jakarta. Pusat kurikulum. Balitbang Depdiknas.

Depdiknas. 2006. Peraturan Menteri Pendidikan Nasional Nomor 22 Tahun 2006 Tentang Standar Isi Sekolah Menengah Pertama. Jakarta: Depdiknas.

Hamalik, Omar. 2007. Evaluasi Kurikulum Pendekatan Sistematik. Bandung: Yayasan Al-Madani Terpadu.

Noornia, Anton. (2011). Cooperative Learning with Metacognitive Approach Ton Enhance Mathematical Critical Thinking And Probelem Solving Ability And the Relation To Self 
Regulated Learning. Jurnal International Seminar and the 4th National Conference on Mathematics Education. Juni 2011.

Presiden RI .(2013). Peraturan Pemerintah Republik Indonesia Nomor 32 Tahun 2013 Tentang Standar Nasional Pendidikan.

Munir, Renaldi. (2013). Metode Numerik. Bandung: Informatika Bandung.

Sianifar, R.H. (2013). Pemrograman Mathlab. Bandung: Informatika Bandung. 
Application Of Mathlab Applications In Improving Student Competence Umsu Mathematics Education Study Program Numerical Method Course 2019-2020 Academic Year

DOI: $10.54443 /$ ijerlas.v1i2.91 